УДК 37.091.12: 005.963]: 37.018.43: 57

DOI https://doi.org/10.26661/2522-4360-2021-2-09

\title{
ЗМІСТ ТА СТРУКТУРА ДИСТАНЦЙНОГО КУРСУ «МЕТОДИКА ФОРМУВАННЯ В УЧНІВ МОТИВАЦІЇ ДО ВИВЧЕННЯ БІОЛОГІЇ»
}

\author{
Цуруль О. А. \\ кандидат педагогічних наук, доцент, \\ доцент кафедри психолого-педагогічних дисииплін \\ Національний педагогічний університет імені М. П. Драгоманова \\ вул. Пирогова, 9, Київ, Україна \\ orcid.org/0000-0002-8298-8395 \\ olgatsurul@ukr.net
}

\begin{abstract}
Ключові слова: дистанційне навчання, освітній проиес з біології, методична підготовка, мотивачія, методика навчання біології, підвищення кваліфікаиії вчителів.
\end{abstract}

У статті розкрито особливості методичної підготовки вчителя біології до формування в учнів мотивації до вивчення біології. Відзначено, що формування відповідної методичної компетентності є важливим напрямом професійного розвитку сучасного вчителя біології. Мотивація $\epsilon$ провідним чинником, що регулює активність, поведінку, діяльність особистості. Будь-яка педагогічна взаємодія вчителя 3 учнем стає ефективною лише 3 урахуванням особливостей навчальної мотивації. Актуальність спеціального дистанційного курсу для вчителів біології посилюється негативною динамікою навчальної мотивації учнів в умовах усесвітньої пандемії, спричиненої коронавірусом SARS-CoV-2. Дистанційний курс «Методика формування в учнів мотивації до вивчення біології» $є$ короткотривалим онлайн-курсом на освітній платформі «Всеосвіта» (30 навчальних годин). В основу розробки курсу покладено авторське навчально-методичне забезпечення методичної підготовки майбутніх учителів біології в Національному педагогічному університеті імені М.П. Драгоманова. Дистанційний курс складається із трьох модулів: «Теоретичні засади формування в учнів мотивації до вивчення біології», «Методичні особливості формування в учнів мотивації до вивчення біології» та «Контрольно-оцінний». Цей курс надає унікальну можливість вивчити інноваційні методи та засоби формування в учнів мотивації до вивчення біології. Сучасні інформаційно-комунікаційні технології дозволяють кожному слухачу підбирати максимально ефективний темп та програму занять. Проєктування навчального процесу здійснено на засадах компетентнісного підходу. Охарактеризовано особливості розгортання змісту курсу на рівні провідних форм організації навчання (лекції, практичні заняття), визначено відповідні результати навчання вчителів біології. Проведено аналіз перших результатів запровадження авторського дистанційного курсу. Усі складники авторського курсу (зміст, завдання, оцінювання) були позитивно відзначені слухачами - учителями біології. У статті наголошується, що малі дистанційні курси $є$ новим напрямом не лише професійного розвитку вчителів, і й перспективною формою сучасної методичної підготовки 


\title{
CONTENT AND STRUCTURE OF DISTANCE COURSE "METHODS OF FORMATION OF THE SECONDARY SCHOOL STUDENTS' MOTIVATION FOR LEARNING BIOLOGY"
}

\author{
Tsurul O. A. \\ Candidate of Pedagogical Sciences, Associate Professor, \\ Associate Professor at the Department of Psychological and Pedagogical Disciplines \\ National Pedagogical Dragomanov University \\ Pyrohova str., 9, Kyiv, Ukraine \\ orcid.org/0000-0002-8298-8395 \\ olgatsurul@ukr.net
}

Key words: distance learning, educational process in biology, methodical training, motivation, methods of teaching biology, teachers' professional development.

\begin{abstract}
The article deals with methodical training of biology teachers to formation of the secondary school students' motivation for learning biology. It is noted that the formation of such methodical competence is an important area of biology teachers' professional development. Motivation is a key factor which regulates activity, behavior and work of personality. Every pedagogical interaction between teacher and pupil becomes efficient only by taking into account his motivation peculiarities. The relevance of a special distance course for biology teachers is exacerbated by the negative dynamics of secondary school student' motivation caused by the COVID-19 pandemic. The distance course "Methods of formation of the secondary school students' motivation for learning biology" is a small online course at the educational platform "Vseosvita" (30 training hours). The basis of creating a course is authorial educational support of methodical training of future teachers of biology at the National Pedagogical Dragomanov University.

The distance course contains 3 modules: "Theoretical background of motivation formation to learn biology", "Methodical features of motivation formation to learn biology" and "Control and evaluation". This course provides a unique opportunity to study the innovative means of education and methods of motivation formation to learn biology. Modern information and communication technologies create opportunities to choose the most effective pace and program for each student. On the basis of competence-based approach carried out the design of the educational process. The peculiarities of realization of course content in different forms of methodical training (lectures and practical classes) are substantiated. The leading competences and methodical system of knowledge and skills are determined. The analysis of first results of introduction of this distance course is made. All the sections of the authorial course (objectives, contents, evaluation, etc.) were favorably evaluated by biology teachers. The article emphasizes that small online course is a new approach to teachers' professional development and promising form of modern methodical training of students-future teachers of biology.
\end{abstract}

Постановка проблеми. Зміна освітньої парадигми, оновлення змісту освітніх галузей, методологічна переорієнтація освітнього процесу на розвиток компетентної особистості зумовлюють оновлення змісту та форм організації пізнавальної діяльності учнів. Перебіг та результативність такої діяльності визначаються насамперед методично правильною організацією процесу формування в учнів мотивації. Мотивація $є$ одним 3 основних рушіїв успішності учнів. Результати міжнародного дослідження якості освіти PISA-
2018 «Для чого чи кого навчаються українські підлітки» [22] та шкільна практика навчання біології свідчать, що актуальною в умовах сьогодення $\epsilon$ методика формування в учнів мотивації до вивчення біології (далі - ФМВБ), побудована на засадах компетентнісно орієнтованого освітнього процесу 3ЗСО. Актуальність посилюється негативною динамікою розвитку мотиваційної сфери учасників освітнього процесу, зумовленою переходом до змішаного й онлайн-навчання в умовах усесвітньої пандемії, спричиненої коронавірусом 
SARS-CoV-2. Тому формування відповідної методичної компетентності є важливим напрямом самоосвіти сучасного вчителя біології, а одним із шляхів iii реалізації є дистанційний курс «Методика формування в учнів мотивації до вивчення біології».

Мета статті полягає в розкритті змісту та структури авторського методичного дистанційного курсу, орієнтованого на розвиток у вчителів-практиків методичної готовності до використання інноваційних засобів, методів та методичних прийомів формування в учнів мотивації до вивчення біології.

Виклад основного матеріалу дослідження. Практико-орієнтований дистанційний курс «Методика формування в учнів мотивації до вивчення біології» [17] передбачає вивчення теоретичних засад та методичних особливостей формування в учнів мотивації в умовах компетентнісно орієнтованого освітнього процесу з біології ЗЗСО.

В основу розробки авторського дистанційного курсу покладено:

1) результати критичного аналізу інформаційних джерел із проблеми розроблення навчальних онлайн-курсів (Т. Волобуєва (2010р.), М. Смульсон (2012 р.), В. Биков (2008 р.)) та проблеми формування в учнів мотивації до вивчення біології:

а) психолого-педагогічні аспекти, досліджені в роботах В. Давидова (1986 р.), С. Занюка (2002 р.), Л. Божович (1972 р.), Т. Гладиш (2012 р.), Є. Ільїна (2000 р.), С. Канюк (2002 р.), В. Ковальова (1988 р.), О. Леонтьєва (2001р.), А. Маркової (1993 p.), I. Скріпкіна (2010р.), S. Vázquez-Toledo [24], L. Wijnia [25];

б) методичні аспекти, розкриті в дослідженнях Г. Опаренюк [8; 9], Т. Пилипченко [10], А. Теремова [12], Л. Шаповал [20], К. Castro [21];

2) результати аналізу сучасної шкільної практики формування в учнів мотивації до вивчення біології, практики методичної підготовки студентів-майбутніх вчителів біології в закладах вищої освіти (далі - 3ВО) та практики організації самоосвіти вчителів біології в межах післядипломної педагогічної освіти;

3) зміст авторського комплексу навчальнометодичного забезпечення 3 дисципліни «Методика навчання біології» $[6 ; 7 ; 13 ; 15 ; 16 ; 19]$;

4) інструктивно-методичні та дидактичні матеріали, створені у процесі власного багаторічного досвіду педагогічної, а також викладацької діяльності на факультеті природничо-географічної освіти та екології Національного педагогічного університету імені М.П. Драгоманова, а саме:

а) викладання нормативної дисципліни «Методика навчання біології»;

б) керівництва виробничими педагогічними практиками майбутніх учителів біології, хімії та географії на базі провідних З3СО м. Києва; в) керівництва науковою роботою бакалаврів та магістрів спеціальності 014.05 «Середня освіта (Біологія та здоров'я людини)» [3; 4; 18];

г) розроблення й упровадження дистанційного курсу «Методика навчання біології» для підготовки бакалаврів заочно-дистанційної форми навчання [14].

Мета курсу - формування готовності до ФМВБ в умовах компетентнісно орієнтованого освітнього процесу 33СО.

Завдання курсу: опанування методики ФМВБ в умовах компетентнісно орієнтованого освітнього процесу, розвиток професійно-методичної компетентності вчителя та формування професійно-методичних умінь.

Очікувані результати навчання охоплюють:

А) знання і розуміння: сутності поняття «мотивація навчальної діяльності»; місця та ролі мотивації у структурі сучасного освітнього процесу 33СО; психолого-педагогічних засад процесу ФМВБ; оптимального добору та поєднання методів, методичних прийомів та засобів навчання у процесі ФМВБ; методичних особливостей ФМВБ засобами інноваційних технологій навчання; основних механізмів функціонування і реалізації компетентнісної парадигми навчання;

Б) розвинені вміння: організовувати педагогічну діяльність на компетентнісних засадах (прогнозування, проєктування, оцінювання тощо); конструювати та реалізувати сучасні програми навчання 3 використанням різноманітних методів, форм і технологій; діагностувати освітній процес і складати індивідуальні освітні маршрути для становлення учня як особистості, громадянина, інноватора; здійснювати добір та поєднання методів, методичних прийомів та засобів навчання у процесі ФМВБ; ФМВБ з урахуванням вікових особливостей учнів; діагностувати актуальний рівень сформованості мотивації до вивчення біології; організовувати культуромовне освітньорозвивальне середовище; проєктувати власну програму професійно-особистісного зростання;

Прогнозовані результати опанування курсу:

- поглиблення розуміння особливостей організації компетентнісно-орієнтованого освітнього процесу у $33 \mathrm{CO}$;

- розуміння місця і ролі методики ФМВБ у контексті реалізації завдань Нової української школи;

- знання психолого-педагогічних засад процесу ФМВБ;

- розуміння методичних особливостей процесу ФМВБ засобами інноваційних технологій навчання;

- розвиток навичок добору та поєднання методів, методичних прийомів та засобів навчання у процесі ФМВБ; 
- розвиток навичок планування освітнього процесу з біології на основі поетапного формування мотивації навчальної діяльності;

- розвиток навичок планування та проведеннях різних видів навчальної діяльності;

- усвідомлення важливості врахування індивідуальних особливостей кожної дитини для створення безпечного й емоційно комфортного освітнього середовища;

- розвиток навичок організації освітнього середовища, орієнтованого на дитину та розвиток спільноти.

Структурування та побудова дистанційного курсу здійснені на основі модульного принципу (табл. 1).

Зупинимось детальніше на змісті навчального дистанційного курсу «Методика формування в учнів мотивації до вивчення біології».

Модуль 1. Теоретичні засади ФМВБ.

Тема 1.1. Поняття про мотивацію як провідний компонент освітнього процесу.

Лекція № 1 «Загальна структура мотиваційної сфери навчання».

План:

1. Поняття «мотив», «мотивація» як змістова основа детермінації поведінки учня.

2. Види та характеристика мотивів.

3. Класифікація мотивів навчання.

4. Типи та види мотивації навчальної діяльності.

Тема 1. 2. Психолого-педагогічна характеристика процесу ФМВБ.

Лекція № 2 «Психолого-педагогічні механізми формування мотиваційної сфери особистості у процесі навчання».

План:

1. Особливості розвитку мотиваційної сфери підлітків.

2. Механізми й етапи формування мотивації навчальної діяльності.
3. Дослідження стану сформованості мотивації навчання - важливий напрям роботи вчителя.

Практична робота № 1 «Загальні наукові засади ФМВБ».

Завдання:

1. Охарактеризуйте поняття «мотив», «мотивація», «навчальна мотивація».

2. Назвіть специфічні фактори, які визначають навчальну мотивацію.

3. Складіть схеми: а) «Класифікація мотивів навчання», б) «Види навчальної мотивації».

5. Ознайомтеся з інструментарієм дослідження стану сформованості в учнів навчальної мотивації [2; 5; 11]. Проведіть анкетування учнів основної школи (1-2 класи) за одним 3 опитувальників (на ваш вибір). Зробіть висновки про стан сформованості в учнів навчальної мотивації та складіть орієнтовну програму формування позитивної мотивації в опитаних учнів.

Модуль 2. Методичні особливості ФМВБ.

Тема 2.1. Добір та поєднання методів, методичних прийомів та засобів навчання у процесі ФМВБ.

Лекція № 3 «Особливості формування позитивної мотивації в умовах реалізації форм та методів навчання».

План:

1. Фактори ФМВБ.

2. Мотиваційні можливості уроку біології та їх поетапна реалізація.

3. Система методів, методичних прийомів та засобів навчання у ФМВБ.

Практична робота № 2 «Методика проєктування процесу ФМВБ».

Завдання:

1. Назвіть провідні фактори мотивації навчання біології.

Таблиця 1

Навчальний план дистанційного курсу «Методика формування в учнів мотивації до вивчення біології»

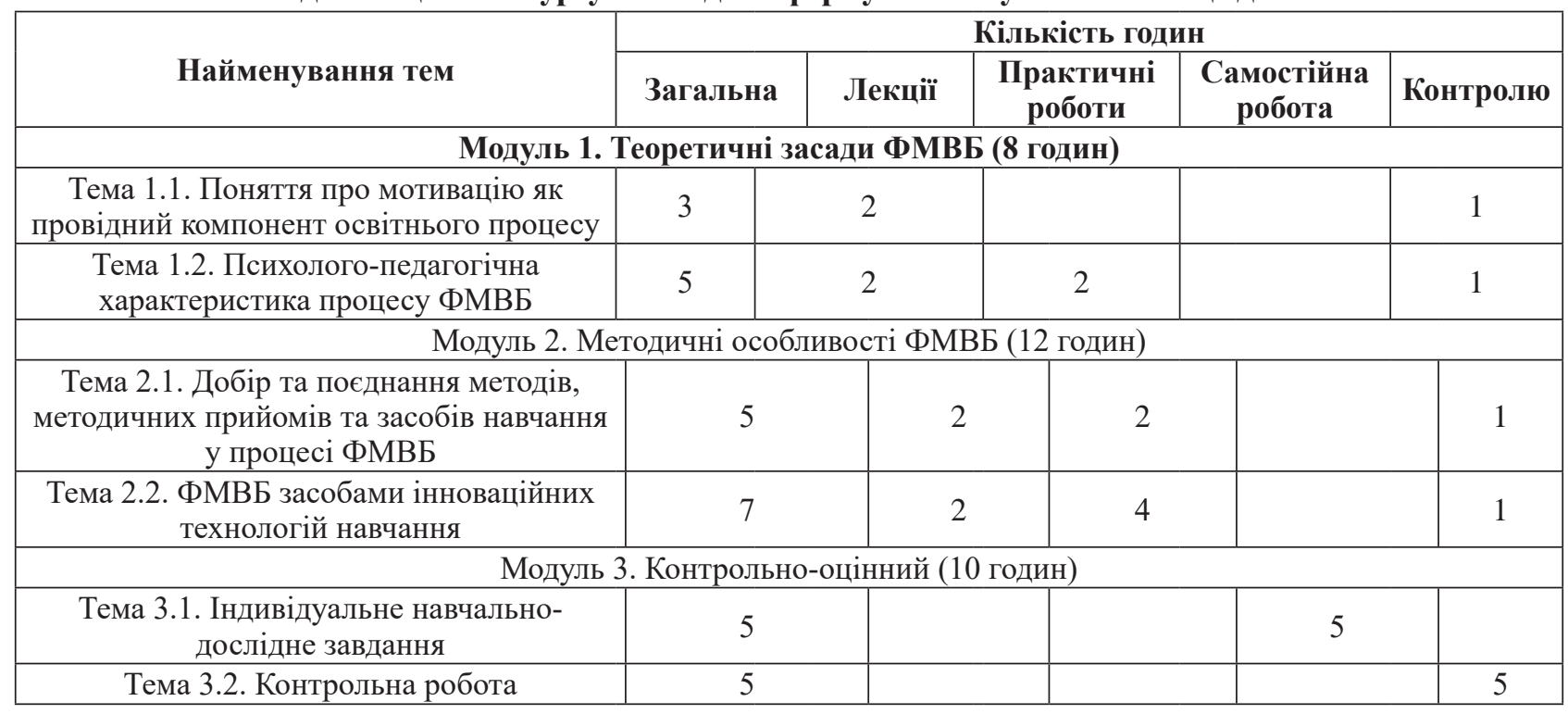


2. Укажіть етапи й охарактеризуйте діяльність учителя під час проєктування мотиваційного циклу уроку біології.

3. За допомогою друкованих і електронних інформаційних джерел здійсніть аналіз шкільної практики ФМВБ, заповніть таблицю (табл. 2).

Таблиця 2

Провідні форми, методи, методичні прийоми ФМВБ

\begin{tabular}{|c|c|c|}
\hline $\begin{array}{c}\text { Вікова } \\
\text { група учнів }\end{array}$ & Вид мотивації & $\begin{array}{c}\text { Форми, методи, } \\
\text { методичні } \\
\text { прийоми } \\
\text { навчання }\end{array}$ \\
\hline \multirow{2}{*}{$\begin{array}{c}\text { Основна } \\
\text { школа }\end{array}$} & вступна & \\
\cline { 2 - 3 } & поточна & \\
\cline { 2 - 3 } & завершальна & \\
\hline \multirow{2}{*}{$\begin{array}{c}\text { Старша } \\
\text { школа }\end{array}$} & вступна & \\
\cline { 2 - 3 } & поточна & \\
\cline { 2 - 3 } & завершальна & \multicolumn{1}{|c|}{} \\
\hline
\end{tabular}

4. Розробіть мотиваційного цикл одного з уроків біології, заповніть таблицю (табл. 3):

Таблиця 3

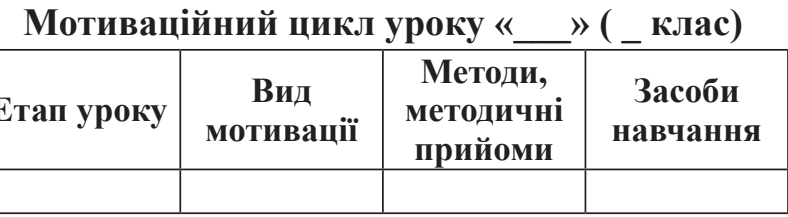

Тема 2.2. ФМВБ засобами інноваційних технологій навчання.

Лекція № 4 «Особливості ФМВБ засобами інноваційних технологій навчання».

План:

1. Методика ФМВБ засобами технологій мобільного навчання.

2. Використання медіаконтенту для ФМВБ.

3. ФМВБ засобами технологій візуалізації «Сторітелінг» та «Скрайбінг».

Практична робота № 3 «Система методів, методичних прийомів та засобів ФМВБ».

Завдання:

1. Охарактеризуйте напрями використання IКТ в освітньому процесі з біології.

2. За допомогою інтернету доберіть тематичні електронні ресурси, заповніть таблицю (табл. 4):

Таблиця 4 Методика використання інтернет-ресурсів для ФМВБ

\begin{tabular}{|c|c|c|c|c|}
\hline Клас & $\begin{array}{c}\text { Тема } \\
\text { уроку }\end{array}$ & $\begin{array}{c}\text { Вид } \\
\text { мотивації }\end{array}$ & $\begin{array}{c}\text { Метод } \\
\text { (методичнй } \\
\text { прийом) } \\
\text { навчання }\end{array}$ & $\begin{array}{c}\text { Інтернет- } \\
\text { джерело }\end{array}$ \\
\hline & & & & \\
\hline
\end{tabular}

Практична робота № 4 «Методика ФМВБ засобами інноваційних технологій навчання».
Завдання:

1. Охарактеризуйте можливості мобільного навчання для ФМВБ.

2. Назвіть напрями використання медіаресурсів для ФМВБ.

3. До однієї з навчальних тем створіть QR-коди для ФМВБ, заповніть таблицю (табл. 5).

Таблиця 5

\begin{tabular}{|c|c|c|c|}
\hline $\begin{array}{c}\text { Tема } \\
\text { уроку }\end{array}$ & $\begin{array}{c}\text { Вид } \\
\text { мотивації }\end{array}$ & QR-код & $\begin{array}{c}\text { Форми, методи, } \\
\text { методичні прийоми } \\
\text { навчання }\end{array}$ \\
\hline & & & \\
\hline
\end{tabular}

\section{Методика використання QR-кодів для ФМВБ}

4. За допомогою інтернету доберіть відеофрагменти, основу яких становить методика сторітелінгу, заповніть таблицю (табл. 6).

Таблиця 6

Методика використання сторітелінгу для ФМВБ

\begin{tabular}{|c|c|c|c|}
\hline $\begin{array}{c}\text { Тема } \\
\text { сторітелінгу }\end{array}$ & $\begin{array}{c}\text { Посилання } \\
\text { на джерело }\end{array}$ & $\begin{array}{c}\text { Тема } \\
\text { уроку }\end{array}$ & $\begin{array}{c}\text { Вид } \\
\text { навчальної } \\
\text { мотивації }\end{array}$ \\
\hline $\begin{array}{c}\text { Історія про } \\
\text { Карасика }\end{array}$ & {$[1]$} & & \\
\hline & & & \\
\hline
\end{tabular}

5. 3 контенту засобів масової інформації доберіть медіаповідомлення для ФМВБ, заповніть таблицю (табл. 7).

Таблиця 7

\begin{tabular}{|c|c|c|c|}
\hline $\begin{array}{c}\text { Назва } \\
\text { 3МI }\end{array}$ & $\begin{array}{c}\text { Тема медіа- } \\
\text { повідомлення, } \\
\text { його вид }\end{array}$ & $\begin{array}{c}\text { Тема } \\
\text { уроку }\end{array}$ & $\begin{array}{c}\text { Форми, методи, } \\
\text { прийоми } \\
\text { навчання }\end{array}$ \\
\hline & & & \\
\hline
\end{tabular}

\section{Методика використання медіаресурсів для ФМВБ}

Модуль 3. Контрольно-оцінний.

Тема 3.1. Індивідуальне навчально-дослідне завдання.

Розробіть (на вибір):

а) мотиваційні цикли до уроків біології з однієї 3 навчальних тем чинної програми;

б) мультимедійну презентацію «Методика використання сторітелінгу (або скрайбінгу - на вибір) для ФМВБ».

Тема 3.2. Контрольна робота.

Упровадження дистанційного курсу «Методика формування в учнів мотивації до вивчення біології» у процес післядипломної педагогічної освіти, 
здійснене на освітній платформі «Всеосвіта», отримало схвальні відгуки від учителів-практиків. Так, зокрема, учителька біології Сніжнянської ЗОШ I-II ст. Погребищенського р-ну Вінницької обл. С. Бобовська зазначає: «Дуже детально і зрозуміло описано поєднання методів, методичних прийомів та засобів навчання у процесі формування в учнів мотивації до вивчення біології; під час опрацювання модулей я ознайомилася 3 новітніми технологіями, які мотивують учнів до сприйняття навчального матеріалу. Цікаві підібрані практичні роботи, які вже апробовано серед учнів мого навчального закладу» [17]. Таку думку поділяє і вчителька біології НВК «Інтелект» м. Одеси T. Каришева, яка відзначає: «Дуже професійно продуманий, виважений курс, який дає змогу користуватися ним в умовах реальної шкільної роботи» [17].
Висновки та перспективи дослідження. Аналіз перших результатів упровадження авторського дистанційного курсу «Методика формування в учнів мотивації до вивчення біології» дає підстави для висновків про його ефективність та перспективність. Усі складники авторського курсу (зміст, завдання, оцінювання) були позитивно відзначені слухачами - учителями біології. Подальші дослідження проблеми вбачаємо в розробленні інших короткотривалих дистанційних курсів, спрямованих на формування методичних компетентностей інноваторів - учителів біології. Уважаємо, що малі дистанційні курси $є$ не лише новим напрямом професійного розвитку вчителів, і й перспективною формою сучасної методичної підготовки студентів майбутніх учителів біології у вітчизняних ЗВО. Їх упровадження вже започатковане в іноземних 3ВО як Small Private Online Courses (SPOC) [23].

\section{ЛIТЕРАТУРА}

1. Історія про Карасика, або весняні турботи риб. URL: https://inlnk.ru/WyjQy (дата звернення: 24.12.2020).

2. Коростелева Т., Курдюкова Н. Диагностика учебных мотивов школьников. Биология в школе. 2005. № 4. С. $23-27$.

3. Козаченко М. Формування позитивної мотивації до вивчення біології в учнів 8 класу. Освіта та наука у вимірах XXI cm. : матеріали Звітно-наукової студентської конференції, м. Київ, 17 квітня 2013 р. Київ, 2013. С. 87-90.

4. Маковецька А., Цуруль О. Формування мотивації до вивчення біології в учнів основної школи. Педагогіка: традииї̈ та інноваціiі : матеріали II Міжнародної науково-практичної конференції, м. Харків, 15-16 травня 2015 р. Херсон, 2015. С. 55-58.

5. Методика Г.М. Казанцевої «Вивчення ставлення до навчання». URL: http://testoteka.narod.ru/ms/1/15.html (дата звернення: 24.12.2020).

6. Методика навчання біології : програма навчальної дисципліни / авт.-уклад. : І. Мороз та ін. Київ : НПУ ім. М.П. Драгоманова, 2012. $28 \mathrm{c}$.

7. Методика навчання біології та природознавства : практикум / за ред. І. Мороза. Київ : НПУ імені М.П. Драгоманова, 2010.143 с.

8. Мотивація на уроках біології: 7-й клас / упоряд. Г. Опаренюк. Київ : Шк. світ, 2011. 120 с.

9. Мотивація на уроках біології: 8-й клас / упоряд. Г. Опаренюк. Київ : Шк. світ, 2012. 120 с.

10. Мотивація на уроках біології: 9-й клас / упоряд. Т. Пилипченко. Київ : Шк. світ, 2014. 128 с.

11. Пашнєв Б. Психодіагностика обдарованості. Харків : Основа, 2007. 128 с .

12. Теремов А. О мотивации учебной деятельности школьников по биологии. Биология в школе. 2014. № 6. С. 15-24.

13. Цуруль О. Хрестоматія з методики навчання біології : навчальний посібник. Київ : НПУ ім. М.П. Драгоманова, 2007. 309 с.

14. Цуруль О. Дистанційний курс «Методика навчання біології»: досвід розробки та впровадження. Збірник наукових праць Тернопільського Національного педагогічного університету імені Володимира Гнатюка. Серія «Педагогіка». 2017. Вип. 1. C. $167-177$.

15. Цуруль О. Збірник завдань для самостійної роботи студентів з методики навчання біології : методичний посібник. Київ : НПУ, 2010.61 c.

16. Цуруль О. Методика навчання біології : силабус нормативної навчальної дисципліни для студентів спеціальності 014.05 «Середня освіта (Біологія та здоров'я людини)» ОР «бакалавр». Київ, 2021. URL: https://inlnk.ru/bnDR4 (дата звернення: 29.07.2021)

17. Цуруль О. Методика формування в учнів мотивації до вивчення біології : дистанційний курс підвищення кваліфікації. 2021 p. URL: https://vseosvita.ua/course/metodyka-formuvannia-v-uchniv-motyvatsii-do-vyvchennia-biolohii-122.html (дата звернення: 29.07.2021).

18. Цуруль О., Нестеренко М. Мотиваційний компонент уроку у змісті методичної підготовки учителя біології. Методика навчання природничих дисииплін у вищій та середній школах : матеріали Міжнародної науково-практичної конференції, м. Полтава, 29-30 травня 2014 р. Полтава, 2014. С. 175-177.

19. Цуруль О. Тестові завдання з методики навчання біології : навчальний посібник. Київ : НПУ імені М.П. Драгоманова, 2010.127 с.

20. Шаповал Л. Мотивація навчальної діяльності на заняттях з методики викладання біології як психолого-педагогічна проблема. Гуманітарний вісник ДВНЗ «Переяслав-Хмельницький держсавний педагогічний університет імені Григорія Сковороди». 2012. Вип. 24. С. $402-407$.

21. Studying natural history far from the museum: the impact of 3D models on teaching, learning, and motivation / K. Castro et al. Journal of Biological Education. 2021. DOI: 10.1080/00219266.2021.1877774.

22. PISA-2018: Україна в центрі уваги. Вип. 1. Для чого чи кого навчаються українські підлітки? URL: https://inlnk.ru/WNP1n (дата звернення: 29.07.2021).

23. The implementation of Small Private Online Courses (SPOC) as a new approach to education / J. Ruiz-Palmero et al. Int J Educ Technol High Educ. 2020. № 17. P. 27. DOI: 10.1186/s41239-020-00206-1.

24. Vázquez-Toledo S., Latorre-Cosculluela C. \& Liesa-Orús M. Un análisis cualitativo de la motivación ante el aprendizaje de estudiantes de educación secundaria. Revista Española De Orientación Y Psicopedagogía. 2021. Vol. 32 (1). P. 116-131. DOI: https://doi.org/10.5944/ reop.vol.32.num.1.2021.30743. 
25. Wijnia L. Students' motivation in secondary and post-secondary education. Educational Psychology. 2020. Vol. 40. № 8. P. $913-916$. DOI: $10.1080 / 01443410.2020 .1813404$.

\section{REFERENCES}

1. Istoriia pro Karasyka, abo vesniani turboty ryb [A story about Karasik, or the spring worries of fish]. URL: https://inlnk.ru/WyjQy (data zvernennia: 24.12.2020).

2. Korosteleva T.V., Kurdyukova N.A. (2005) Diagnostika uchebnykh motivov shkolnikov [Diagnostics of the educational motives of schoolchildren]. Biology at school. Vol. 4. P. 23-27.

3. Kozachenko M.S. (2013) Formuvannia pozytyvnoi motyvatsii do vyvchennia biolohii v uchniv 8 klasu [Formation of positive motivation to study biology in 8th class students]. Osvita ta nauka u vymirakh XXI stolittia : materialy zvitno-nauk. stud. konf. (Kyiv, 17 kvit. 2013 r.). P. 87-90.

4. Makovetska A.S., Tsurul O.A. (2015) Formuvannia motyvatsii do vyvchennia biolohii v uchniv osnovnoi shkoly [Formation of motivation to study biology in primary school students]. Pedahohika: tradytsii ta innovatsii : Materialy II Mizhnar. nauk.-prakt. konf. (Kharkiv, 15-16 travnia 2015 r.). P. 55-58.

5. Metodyka H.M. Kazantsevoi "Vyvchennia stavlennia do navchannia" [Methodology G.M. Kazantseva "Study of attitudes to learning"]. URL: http://testoteka.narod.ru/ms/1/15.html (data zvernennia: 24.12.2020).

6. Metodyka navchannia biolohii : Prohrama navch. dystsypliny [Methods of teaching biology: Curriculum disciplines]. Avt.-uklad. : I.V. Moroz ta in. Kyiv : NPU imeni M.P. Drahomanova, 2012. 28 p.

7. Metodyka navchannya biolohii ta pryrodoznavstva : Praktykum [Methods of teaching biology and natural sciences: Laboratory Manual]. Za red. I.V. Moroza. Kyiv : NPU imeni M.P. Drahomanova, 2010. 143 p.

8. Motyvatsiia na urokakh biolohii: 7 klas [Motivation in biology lessons: 7'th class]. Uporiad. H.A. Opareniuk. Kyiv : Shk. svit, 2011. 120 p.

9. Motyvatsiia na urokakh biolohii: 8 klas [Motivation in biology lessons: 8th class] Uporiad. H.A. Opareniuk. Kyiv : Shk. svit, 2012. $120 \mathrm{p}$.

10. Motyvatsiia na urokakh biolohii: 9 klas [Motivation in biology lessons: 9th class]. Uporiad. T. Pylypchenko. Kyiv : Shk. svit, 2014. $128 \mathrm{p}$.

11. Pashniev B.K. (2007) Psykhodiahnostyka obdarovanosti [Psychodiagnostics of giftedness]. Kharkiv : Osnova. 128 p.

12. Teremov A.V. (2014) O motivatsii uchebnoy deyatelnosti shkolnikov po biologii [About the motivation of the educational activity of schoolchildren in biology]. Biology at school. Vol. 6. P. 15-24.

13. Khrestomatiia z metodyky navchannia biolohii: navch. posib. [A textbook on methods of teaching biology]. Avtor-uklad. O.A. Tsurul. Kyiv : NPU imeni M.P. Drahomanova, 2007. 309 p.

14. Tsurul O.A. (2017) Dystantsiinyi kurs "Metodyka navchannia biolohii”": dosvid rozrobky ta vprovadzhennia [Distance course "Methods of teaching biology": experience of development and introduction]. The Scientific Issues of Ternopil Volodymyr Hnatiuk National Pedagogical University. Series: pedagogy Vol. 1. P. 167-177.

15. Tsurul O.A. (2010) Zbirnyk zavdan dlia samostiinoi roboty studentiv z metodyky navchannia biolohii: metod. posib [Collection of tasks for students' self - study work on the methods of teaching biology]. Kyiv : NPU. $61 \mathrm{p}$.

16. Tsurul O.A. (2021) Metodyka navchannia biolohii : sylabus normatyvnoi navch. dystsypliny [Methods of teaching biology : syllabus]. URL: https://inlnk.ru/bnDR4 (data zvernennia: 29.07.2021).

17. Tsurul O.A. (2021) Metodyka formuvannia v uchniv motyvatsii do vyvchennia biolohii : dystantsiinyi kurs pidvyshchennia kvalifikatsii [Methods of formation of the secondary school students' motivation for learning biology : distance teachers' professional development course]. URL: https://vseosvita.ua/course/metodyka-formuvannia-v-uchniv-motyvatsii-do-vyvchennia-biolohii-122.html (data zvernennia: 29.07.2021)

18. Tsurul O.A., Nesterenko M.S. (2014) Motyvatsiinyi komponent uroku u zmisti metodychnoi pidhotovky uchytelia biolohii [Motivational component of the lesson in the content of methodical training of a biology teacher]. Metodyka navchannia pryrodnychykh dystsyplin $u$ vyshchii ta serednii shkolakh : materialy mizhnar. nauk.-prakt. konf. (Poltava, 29-30 travnia 2014 r.). P. 175-177.

19. Tsurul O.A. (2010) Testovi zavdannia z metodyky navchannia biolohii : navch. posib. [Tests on the methods of teaching biology]. Kyiv : NPU. $127 \mathrm{p}$.

20. Shapoval L.V. (2012) Motyvatsiia navchalnoi diialnosti na zaniattiakh z metodyky vykladannia biolohii yak psykholoho-pedahohichna problema [Motivation of educational activity in classes on methods of teaching biology as a psychological and pedagogical problem]. The journal of humanities state higher educational establishment "Pereyaslav-khmelnytskyi State Pedagogical University named after Hryhoriy Skovoroda" Vol. 24. C. 402-407.

21. Castro K., Amado T., Bidau C. \& Martinez P. Studying natural history far from the museum: the impact of 3D models on teaching, learning, and motivation. Journal of Biological Education. 2021. DOI: 10.1080/00219266.2021.1877774.

22. PISA-2018: Ukraina $v$ tsentri uvahy. Vyp. 1. Dlia choho chy koho navchaiutsia ukrainski pidlitky? [PISA-2018: Ukraine is in the spotlight. Vol. 1. What or whom do Ukrainian teenagers' study for?]. URL: https://inlnk.ru/WNP1n (data zvernennia: 29.07.2021).

23. Ruiz-Palmero J., Fernández-Lacorte J.M., Sánchez-Rivas E. et al. The implementation of Small Private Online Courses (SPOC) as a new approach to education. Int J Educ Technol High Educ. 2020. 17, 27. DOI: 10.1186/s41239-020-00206-1.

24. Vázquez-Toledo S., Latorre-Cosculluela C. \& Liesa-Orús M. Un análisis cualitativo de la motivación ante el aprendizaje de estudiantes de educación secundaria. Revista Española De Orientación Y Psicopedagogía. 2021. Vol. 32 (1). P. 116-131. DOI: 10.5944/reop.vol.32. num.1.2021.30743.

25. Wijnia L. Students' motivation in secondary and post-secondary education. Educational Psychology. 2020. Vol. 40. № 8. P. $913-916$. DOI: $10.1080 / 01443410.2020 .1813404$. 